\title{
Smoking, Health Market Equilibrium and Fiscal Policy
}

Efraín Sánchez González MD, Fé Fernández Hernández MD $^{1 *}$

${ }^{1}$ Auxiliary Professor. Faculty of Medical Science at University of Medical Science of Havana.

*Corresponding Author: Fé Fernández Hernández, Auxiliary Professor. Faculty of Medical Science at University of Medical Science of Havana.

\section{Received Date: 05 July 2021 | Accepted Date: 07 August 2021 | Published Date: 17 August 2021}

Citation: Efraín S González, Fé F Hernández. (2021) Smoking, Health Market Equilibrium and Fiscal Policy. Journal of Clinical and Laboratory Research. 3(3); DOI:10.31579/2768-0487/036

Copyright: (c) 2021 Fé Fernández Hernández. This is an open-access article distributed under the terms of the Creative Commons Attribution License, which permits unrestricted use, distribution, and reproduction in any medium, provided the original author and source are credited.

\section{Abstract}

Introduction: The application of and effective fiscal policy for the smoking control in the health context begins understanding the smoking impact over the health market equilibrium.

Objective: To describe the basic relation between the health market equilibrium and the application of a fiscal policy for the appropriate smoking control.

Materials and methods: Was made a descriptive research about the basic relation between the health market equilibrium and the application of a fiscal policy for the appropriate smoking control. As teoric methods were used the descriptive, the comparative and the historic - logic. As empiric method was used the bibliographic research. The graphs were designed by Microsoft Excel 2007.

Results: Society would be better without smoking and fiscal authorities must acknowledge it and take decision agree to that fact. These authorities need induce to smokers to reduce the tobacco consumption. For that fiscal authorities need understand the main causes from the tobacco consumption beginning and keeping.

Conclusion: Tobacco consumption intensity growing carries to increase the price equilibrium from this market and much patients leave from this market because of smoking impact. That's why the fiscal authorities must use the fiscal policies carrying the population to a context with lowest smoking impact over the health services market.

Key words: smoking; health market equilibrium; fiscal policy

\section{Introduction:}

The health market equilibrium research is very important for an effective health services management. Understand the health service demand behavior provide to health services suppliers the possibility to make a better planning about economic resources utilization. Socially may research the relation between morbidity and health services demand and thus deduce how much morbidity causes become in effective demand of health services [1].

Also may understand the relation between health spend and the morbidity and mortality attributable to some illnesses or risk factors as smoking, for example. Especially in cases as this one make show the social opportunity cost attributable to the illness or risk factor researched providing the health services related to the researched population [2].

Tobacco consumption is largely extended around the world and consequently smoking as risk factor too [3]. Smoking is close related to no - communicable illness and constitutes a relevant modifiable cause of morbidity and mortality happening [4]. Also, thesmoking selfcharacteristics had carried to fiscal authorities to control it reducing the tobacco consumption across the implementation of appropriate fiscal policies, especially in countries where the health services provisions occur across the public sector [5].

The application of and effective fiscal policy for the smoking control in the health context begins understanding the smoking impact over the health market equilibrium. The characteristics and the magnitude of this impact determine the particular characteristics from the appropriate fiscal policy for the smoking control [6].

\section{Objective}

To describe the basic relation between the health market equilibrium and the application of a fiscal policy for the appropriate smoking control.

\section{Materials and methods}

Was made a descriptive research about the basic relation between the health market equilibrium and the application of a fiscal policy for the appropriate smoking control. As teoric methods were used the descriptive, the comparative and the historic - logic. As empiric method was used the 
bibliographic research. The graphs were designed by Microsoft Excel 2007.

\section{Results}

Agree to the population growing and the population aging in a scenario where the smoking effects are null, is expectable an increase from the social morbidity. However, smoking determines a direct proportional relation with tobacco intensity consumption. Considering the accumulative effects from smoking over morbidity, illness because of smoking will be growing accelerated front of tobacco intensity consumption agree to the tobacco consumption intensity increase, as shows the following graph [7].

Social morbidity behavior agree to smoking consumption intensity

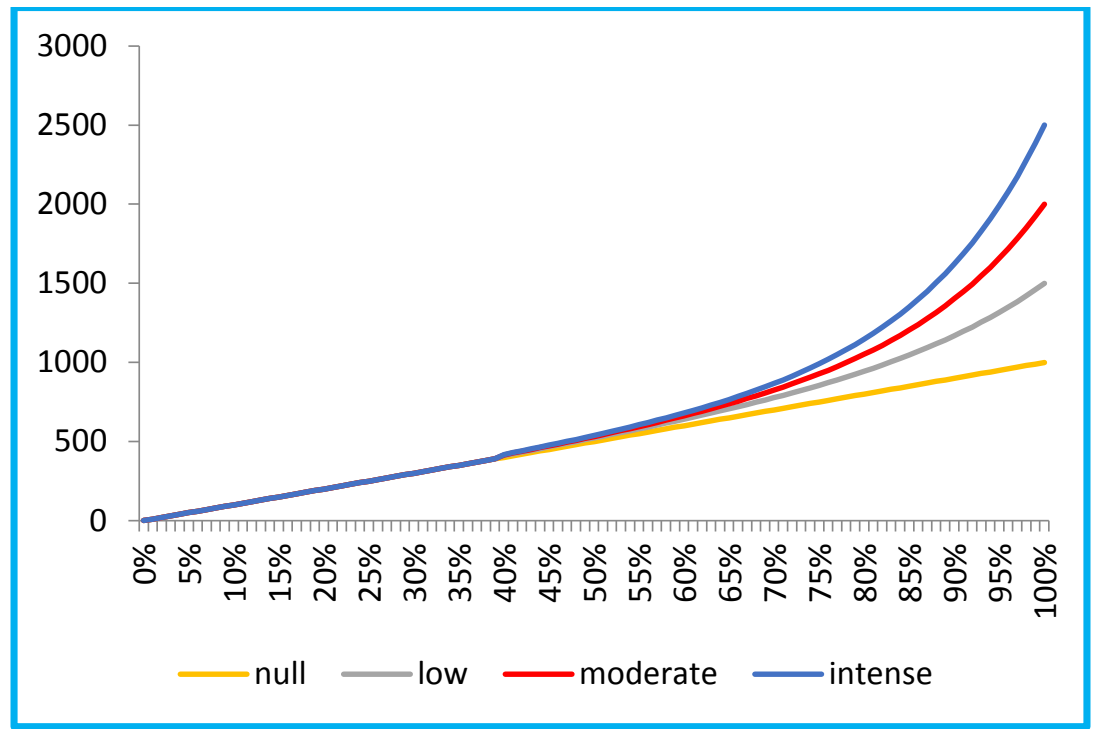

Orange line: social morbidity with smoking null effect
Green line: social morbidity with smoking low effect
Red line: social morbidity with smoking moderate effect
Blue line: social morbidity with smoking intense effect

Addiction to nicotine increase agrees to the tobacco intensity consumption [8]. Smokers experiments the increased need to continue consuming tobacco although acknowledge the toxic effects from this consumption. This behavior determines that smokers are agree paying more for the following unit o tobacco consumption and consequently the smoking impact over personal health be higher showing multi - morbidity causes attributed to smoking in much cases [9]. As result of this behavior smokers will increase the effective demand of health services agree to the intensity of tobacco consumption, as show the following graph.

Effect of tobacco consumption over the health market equilibrium

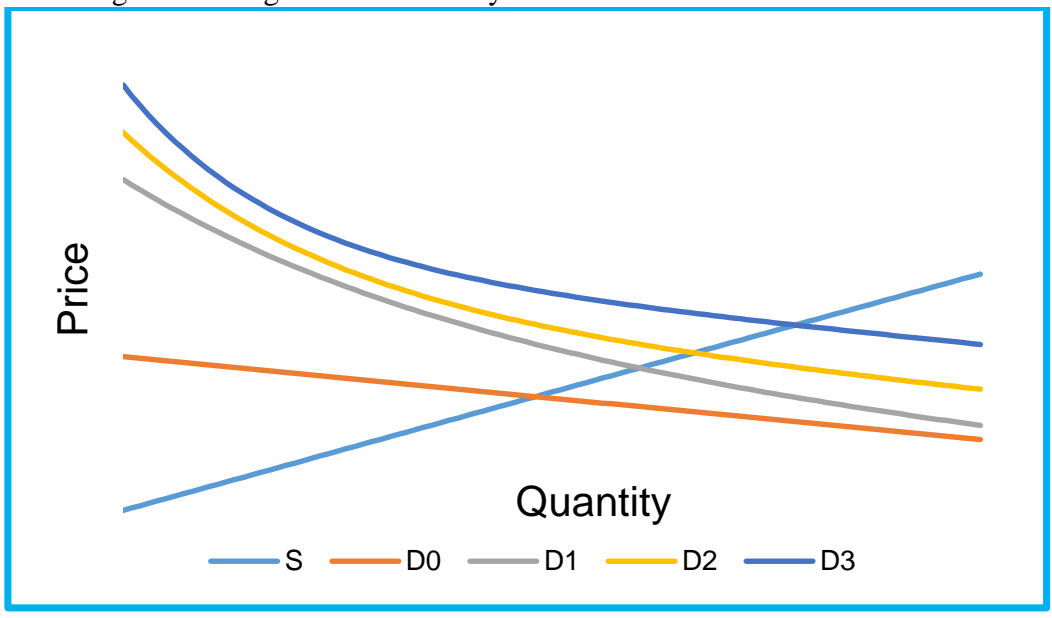

S: Supply of health services;

D0: health services demand without tobacco effects;

D1: health services demand with low tobacco consumption;

D2: health service demand with moderate tobacco consumption;

D3: health services demand with intense tobacco consumption. 
However, the effective increase form the health services demand depend from the health services supplier capability. In some context the health service supply might be close to whole capability and hasn't real possibilities to provide a significant increase in health services supply to cover the health services demand induced by smoking. In case as this the health services market equilibrium move to a closer quantity but to higher price agree to the health services demand induced because of smoking. This is the context where is more evident the socioeconomic inequity attributable to smoking in the consumption of health services because of the bigger number of persons who must leave the health service market because can't afford the new costs induced by smoking.

In population where person numbers don't change, the increase of health services demand is wholly determined by tobacco consumption behavior. This raising isn't automatically because people who can't afford the new conditions induced by smoking must leave the health market. However, health business might raise profits agree to the tobacco consumption growing. Then, don't would be suppressive if health business and tobacco business should assume the same side because for both businessesthe most important is the profit. That's why is important to considerate the health as a superior good, although the health services had been considered a simple good or service [10].

It is evident that society would be better without smoking and fiscal authorities must acknowledge it and take decision agree to that fact. It is a real fact that fiscal authorities could increase tax income at short time from businesses benefited because of smoking [11].

However, morbidity and mortality impact because of smoking is higher and the role from fiscal authorities make responsible to them because the smoking impact over the society.Fiscal authorities need understand that much from the social cost because of morbidity and mortality attributable to smoking would be afforded by fiscal spends and all taxes obtained usually aren't sufficient to cover these spends [12]. Also, any financial income from tobacco industry may cover some untouchable social costs attributable to smoking as reduction in life quality or life expectancy, for example [13].

Fiscal authorities need induce to smokers to reduce the tobacco consumption. To obtain this reduction can use the tributary policy and increase the tobacco price by taxes. This policy is more effective agree to lower tobacco consumption and initially has a more preventive effect to beginner smokers. However, smokers with higher tobacco consumption intensity will reduce the tobacco consumption in less proportion that the tobacco price increase and fiscal authorities must use the no tributary policy to induce to smokers to reduce the tobacco consumption [14].

For that the fiscal authorities need understand the main causes from the tobacco consumption beginning and keeping. Identify these causes may possible the designing of effective policies to reduce, minimize and eliminate the main causes favorable to tobacco consumption. That's why should be important the simultaneous useful from tributaries and no tributaries policies for the smoking control [15].

In reference to the fiscal policies use is important take account that each one intervention from the fiscal authorities in the health market will cause a social cost with negative effects for suppliers and demanders. However, the position of don't intervention is always socially more expensive. The passive fiscal position front of tobacco consumption growing doesn't contribute to reduce the smoking impact over morbidity and mortality neither. Moreover that these authorities have the social responsibility to provide a better welfare estate to population and that include an effective smoking control [16].

Also, economic benefits related to the social health state usually are more significant. These are associated to better useful from the working time, more labor productivity and more profits distributed around all economic sector and don't a few part between a reduced businesses number close related to smoking. People who would be excluded from the health market because of smoking might have new opportunities in a social context where the fiscal policy for the smoking control has a strong position. Then, fiscal authorities must consider the economic policy for the smoking control as useful tool to provide a better welfare for all persons especially to those who must leave the health market because of smoking [17].

\section{Conclusion}

Health services market equilibrium is close related to smoking behavior. Tobacco consumption intensity growing carries to increase the price equilibrium from this market and much patients leave from this market because of smoking impact. That's why the fiscal authorities must use the fiscal policies carrying the population to a context with lowest smoking impact over the health services market.

\section{References:}

1. Ho K, R.S. Lee. (2019). "EquilibriumProvider Networks: Bargaining and Exclusion in HealthCareMarkets".American EconomicReview. 109 (2): 473-522.

2. Zhang, W. (2018) Health and Wealth in a Dynamic General EquilibriumTheory. EcoforumJournal. 7(2).

3. Hoffman S J, Poirier M J P, Rogers Van Katwyk S, Baral P, Sritharan L. (2019). Impact of the WHO Framework ConventiononTobacco Control on global cigaretteconsumption: quasi-experimental evaluationsusinginterrupted time series analysis and insampleforecasteventmodelling BMJ. 365: 12287.

4. Gambaryan M, Reeves A, Deev A, Popovich M, et .al. (2018). Effects of tobacco control policyon cardiovascular morbidity and mortality in Russia. EuropeanJournal of PublicHealth. 28(2):14-16.

5. Flor, L.S, Reitsma, M.B, Gupta, V. et al. (2021). Theeffects of tobacco control policieson global smoking prevalence. NatMed. 27: 239-243.

6. Chaiton M, Dubray J, Guindon GE, Schwartz R. (2021). TobaccoEndgameSimulationModelling: AssessingtheImpact of Policy Changeson Smoking Prevalence in 2035. Forecasting. 3(2):267-275.

7. SanchezGonzalez E., FernandezHernandez F. (2019). A view for the morbidity attributable to smoking since the microeconomic. Trends in Research.

8. Baumeister R. (2017). Addiction, cigarette smoking, and voluntary control of action: Do cigarette smokers lose their free will? Addictive Behaviors Reports. 5: 67-84.

9. Nazir MA, Almas K. (2017). Awareness about the effects of tobacco consumption on oral health and the possibility of smoking behavior among male Saudi schoolchildren. Eur J Dent. 11: 29-35.

10. Tudor-Sfetea C, Rabee R, Najim M, Amin N, Chadha M, Jain M, Karia K, Kothari V, Patel T, Suseeharan M, Ahmed M, Sherwani Y, Siddiqui S, Lin Y, Eisingerich A. (2018). Evaluation of Two Mobile Health Apps in the Context of Smoking Cessation: Qualitative Study of Cognitive Behavioral Therapy (CBT) Versus Non-CBT-Based Digital Solutions. JMIR MhealthUhealth. 6(4): 98.

11. Sánchez Gonzalez E, Fernández Hernandez F. (2018). Tributary policy related to smoking control in Cuba. Correo Científico Médico. 22(2): 238-249.

12. Sánchez Gonzalez E, Fernández Hernandez F. (2017). The role of fiscal authorities in the control of smoking. Rev Ciencias Médicas. 21(3): 362-367. 
13. Fernández Hernández F, Sánchez González E. (2021). El control del tabaquismo en el nuevo modelo económico cubano.

14. Fernández Hernández F, Sánchez González E. (2017). Impacto del tabaquismo en el presupuesto sanitario de Cuba 1997-2014. Rev. Hosp. Psiq. Habana.

15. Sánchez González E., Fernández Hernández F. (2020). BriefAppointmentsabout Fiscal Policyforthe Smoking Control. J Clinical Research and Reports. 2(5).
16. Abuselidze G. (2018). Optimal Fiscal Policy - Factors for the Formation of the Optimal Economic and Social Models. J. Bus. Econ. Review. 3 (1):18-27.

17. Perera S, Vaikuntam B, John D, Senanayake B. (2020). Designing an Optimum Fiscal Policy for Tobacco to Maximise theTax Revenue, Social Savings and the Net Monetary Benefits in Sri Lanka. International Journal of Health Policy and Management. 9(6): 250-256.
This work is licensed under Creative Commons Attribution 4.0 License

To Submit Your Article Click Here: Submit Article

DOI: $10.31579 / 2768-0487 / 036$
Ready to submit your research? Choose Auctores and benefit from:

* fast, convenient online submission

* rigorous peer review by experienced research in your field

* rapid publication on acceptance

* authors retain copyrights

* unique DOI for all articles

* immediate, unrestricted online access

At Auctores, research is always in progress.

Learn more www.auctoresonline.org/journals/journal-of-clinical-andlaboratory-research 